\title{
Wpływ wilgotności gruntów mineralnych na wartość efektywnej przewodności termicznej na podstawie wyników pomiarów laboratoryjnych
}

\author{
Aleksandra Lukawska ${ }^{1}$, Mateusz Żeruń1 ${ }^{1}$, Grzegorz Ryżyński ${ }^{1}$
}

\begin{abstract}
Influence of moisture content of mineral soils on the value of effective thermal conductivity based on the results of laboratory measurements. Prz. Geol., 69: 604-610; doi: 10.7306/2021.34

A b s t r a c t. The article presents the results of laboratory tests of thermal conductivity of mineral soils. Measurements were performed on the basis of the previously developed methodology. Knowledge of values of the thermal conductivity coefficient of soil is essential for the design of installations that use thermal properties of subsoil for energetic purposes. The results of the measurements are stored in the rock and soil thermal properties database, in which additional physical parameters of soils are collected as well. Based on the information from the database, the authors presented the relationship between soil moisture (non-cohesive soils), the liquidity index (cohesive soils), and their thermal conductivity.
\end{abstract}

Keywords: thermal properties of soil, effective thermal conductivity of soil, transient line source method, soil laboratory testing

Określenie wartości parametrów termicznych ośrodka gruntowego znajduje zastosowanie w wielu dziedzinach związanych z energetyką. Rozwój odnawialnych źródeł energii i świadomość konieczności rezygnacji z paliw kopalnych szczególnie przyczyniły się do wzrostu zainteresowania właściwościami termicznymi gruntów i skał (Kłonowski i in., 2020). Wiedza o ww. parametrach jest kluczowa podczas projektowania i wykonania instalacji takich jak gruntowe wymienniki ciepła (Florides i in., 2011; Vieira $\mathrm{i}$ in., 2017; Ramos i in., 2018). Coraz szersze zastosowanie znajdują aktywne termicznie elementy posadowienia budynków, wykorzystujące proces wymiany ciepła pomiędzy elementem konstrukcji budowlanej a ośrodkiem gruntowo-skalnym, takich jak: termopale, termoaktywne fundamenty, termoaktywne ściany tuneli (Ryżyński, Bogusz, 2016; Bogusz, 2017; Baralis i in., 2018). Właściwości termiczne gruntów pełnią także kluczową rolę w określaniu możliwości rozproszenia energii cieplnej w przypadku podziemnej infrastruktury przesyłowej, czyt. kable wysokiego napięcia, sieć grzewcza (Anders, Radhakrishna, 1988), oraz składowania odpadów radioaktywnych (Popov i in., 2016).

Skapa ilość dostępnych informacji dotyczących parametrów termicznych gruntów wymusiły opracowanie metodyki pozwalającej na wykonywanie seryjnej ilości prawidłowych i powtarzalnych oznaczeń w możliwie najkrótszym czasie. Dane dotyczące właściwości termicznych gruntów i skał stanowią podstawę parametryzacji geotermalnych modeli 3D i wykonywania map potencjału geotermii niskotemperaturowej (Ryżyński i in., 2020).

W artykule zostały zaprezentowane wyniki laboratoryjnych pomiarów efektywnej przewodności termicznej gruntów mineralnych, wykonanych na podstawie opracowanej w Centrum Badań Gruntów i Skał (CBGS) Państwowego Instytutu Geologicznego - Państwowego Instytutu Badawczego (PIG-PIB) metodyki badania właściwości termicznych gruntów (Ryżyński i in., 2018; Łukawska i in., 2020). Wszelkie dane na temat próbek i wartości pomiarów są gromadzone w bazie danych właściwości termicznych gruntów i skał.

\section{PODSTAWA TEORETYCZNA POMIARU PRZEWODNOŚCI TERMICZNEJ GRUNTU}

Przewodzenie ciepła to zjawisko polegające na przenoszeniu energii wewnątrz ośrodka materialnego lub pomiędzy ośrodkami będącymi w bezpośrednim kontakcie. Energia jest transportowana $\mathrm{z}$ miejsc o temperaturze wyższej do miejsc o temperaturze niższej. W gazach oraz cieczach energia jest przenoszona głównie poprzez bezwładne zderzenia cząsteczek. W ciałach stałych transport zachodzi przy udziale swobodnych elektronów oraz w wyniku drgań atomów sieci krystalicznej ośrodka. Zjawisko to zostało opisane prawem Fouriera - natężenie strumienia cieplnego jest proporcjonalne do gradientu temperatury mierzonego wzdłuż kierunku przepływu ciepła (Farouki, 1981; Robertson, 1988).

Prawo Fouriera obowiązuje we wszystkich stanach skupienia. Stosuje się je zarówno dla przepływu ciepła w warunkach ustalonych (gdy temperatura w każdym punkcie danego ciała jest niezmienna), jak i przepływu ciepła w warunkach nieustalonych (gdy temperatura danego ciała jest zmienna)

Zasada pomiaru przewodności cieplnej w stanie ustalonym polega na określeniu strumienia ciepła migrującego przez badaną próbkę o znanych wymiarach oraz na pomiarze spadku temperatury. Pomiar odbywa się na powierzchni próbki mającej kontakt ze źródłem ciepła oraz na styku powierzchni próbki z czujnikiem temperatury. Wykonanie pomiaru w warunkach ustalonego przewodzenia ciepła jest procesem pracochłonnym. W założeniach metodycznych korzysta się ze złożonych układów kontrolno-regulacyjnych stanowiska badawczego. Czas uzyskania stanu ustalonej wymiany ciepła w próbce, a więc i wykonywania pomiarów jest długi.

Metody pomiarowe określające wartość przewodności cieplnej ośrodka w stanie nieustalonym polegają na określeniu zależności między gęstością strumienia cieplnego emitowanego ze stałego źródła ciepła a zmieniającą się w czasie temperaturą w warunkach nieustalonego przepływu energii przez badany materiał. Metody oparte na po-

\footnotetext{
${ }^{1}$ Państwowy Instytut Geologiczny - Państwowy Instytut Badawczy, ul. Rakowiecka 4, 00-975 Warszawa; alukaw@pgi.gov.pl; mzer@pgi.gov.pl
} 
miarze w stanie nieustalonym charakteryzują się znacznie większą szybkością wykonania badania niż metody pomiaru w stanie ustalonym, są bardziej wszechstronne i łatwe do wykonania (Maglić i in., 1992). Przedstawione w artykule badania efektywnej przewodności cieplnej gruntów zostały przeprowadzone w warunkach nieustalonych metodą igły termicznej.

Metoda igły termicznej (thermal needle, hot wire method) polega na umieszczeniu $\mathrm{w}$ badanej próbce sondy igłowej o określonej oporności, przez którą przepływa prąd stały o znanym natężeniu. Przepływ prądu powoduje wzrost temperatury sondy, która staje się liniowym źródłem ciepła w badanej próbce. Strumień ciepła wytworzony w trakcie badania jest stały. Pomiar odbywa się pośrednio poprzez określenie tempa nagrzewania badanej próbki (Maglić i in., 1992). Jednostką współczynnika przewodzenia ciepła w układzie SI jest $\mathrm{W} /(\mathrm{m} \cdot \mathrm{K})$, gdzie $\mathrm{W}$ - wat, $\mathrm{m}$ - metr, K kelwin. W efekcie możliwe jest ustalenie zarówno wzrostu, jak i spadku temperatury ośrodka. Podstawy teoretyczne zostały opisane szerzej w artykule Łukawskiej i in. (2020).

\section{METODYKA PROWADZENIA POMIARÓW}

Sposób przygotowania próbek gruntów do badania przewodności termicznej różni się w zależności od rodzaju gruntu oraz klasy pobranej próbki. Oznaczanie parametrów cieplnych gruntów na potrzeby uzupełniania bazy prowadzi się na dwóch podstawowych rodzajach próbek: o nienaruszonej strukturze (NNS) oraz na próbkach o naturalnej wilgotności (NW; klasyfikacja zgodnie z PN-B-04481:1988). W polskiej praktyce geotechnicznej większość pobieranych prób gruntu stanowią próbki o naturalnej wilgotności (NW; metoda B pobierania próbek wg PN-EN 1997-2:2007).

Formowanie gruntu o naturalnej wilgotności prowadzi się w taki sposób, aby uzyskana próbka miała gęstość objętościową jak najbardziej zbliżoną do wartości literaturowych (Myślińska, 2006; Łukawska i in., 2020).

Pomiary efektywnej przewodności cieplnej wykonuje się na próbkach o różnej wilgotności i gęstości objętościowej. Dokładny schemat postępowania z próbkami został przedstawiony na rycinie 1 .

W celu określenia wpływu parametrów fizycznych na otrzymane wyniki przewodności cieplnej wykonuje się oznaczenie wilgotności naturalnej, składu granulometrycznego, parametrów konsystencji, gęstości objętościowej (dla gruntów spoistych) i stopnia zagęszczenia (dla gruntów niespoistych). Wszystkie badania towarzyszące są przeprowadzane zgodnie z wytycznymi polskich i międzynarodowych norm branżowych (PN-B-04481:1988, PN-EN ISO 17892).

Wartości efektywnej przewodności termicznej gruntów otrzymane w laboratorium na próbkach formowanych wg cytowanej metodyki (Lukawska i in., 2020) porównano z wartościami przewodności termicznej uzyskanymi na próbkach o nienaruszonej strukturze (NNS) oraz w trakcie badań terenowych in situ. Zestawione wyniki wykazały znaczną zbieżność, tzn. nie przekraczały błędu pomiarowego urządzenia - $10 \%$.

\section{METODYKA BADAŃ LABORATORYJNYCH}

Do wykonywania badań parametrów cieplnych gruntów stosuje się analizator właściwości termicznych KD2 Pro wraz z zestawem sond - igieł termicznych (KD2 Pro Thermal Properties Analyzer Operator's Manual, 2016). Do formowania próbek o NW wykorzystuje się zestaw urządzeń pomocniczych - metalowe cylindry, ubijak do gruntów spoistych oraz widełki do zagęszczania gruntów niespoistych. W celu eliminacji wypływu czynników środowiskowych na stabilność pomiaru próbki przez cały czas trwania pomiaru znajdowały się w inkubatorze termicznym, utrzymującym zadaną temperaturę. Wszystkie badania efektywnej przewodności termicznej przeprowadzono w temperaturze $10^{\circ} \mathrm{C}$.

Do pomiaru efektywnej przewodności termicznej gruntu wybiera się odpowiednią długość i średnicę sondy termicznej w zależności od rodzaju badanego materiału. Na każdej podpróbce prowadzi się trzy pomiary przewodności termicznej. Potrójny pomiar na każdej z podpróbek pozwala na eliminację błędu, identyfikację nieprawidłowych odczytów oraz statystyczne opracowanie wyników. Zgodnie z zaleceniami producenta, uzyskany wynik uważa się za prawidłowy, jeśli dwa kolejne pomiary nie różnią się od siebie o więcej niż 10\%. Metodyka prowadzenia seryjnych oznaczeń laboratoryjnych przewodności cieplnej gruntów została szczegółowo przedstawiona w artykule Łukawskiej i in. (2020).

\section{WYNIKI BADAŃ LABORATORYJNYCH}

Parametry termiczne otrzymane podczas badań laboratoryjnych przeprowadzonych na ponad 360 próbkach gruntów spoistych i niespoistych z różnych rejonów Polski zostały zestawione w bazie danych. Oprócz pomiarów właściwości termicznych w bazie znajdują się informacje dotyczące właściwości fizycznych (wilgotność, gęstość objętościowa, porowatość, parametry uziarnienia i konsystencji), zawartości materii organicznej i węglanów, uproszczonego składu mineralnego, genezy i stratygrafii oraz współrzędnych punktu poboru próbki.

Analizowane grunty należy rozpatrywać jako ośrodek trójfazowy, w którym każda z faz charakteryzuje się innymi wartościami przewodności cieplnej. Dla badanych gruntów są one następujące:

- faza gazowa - powietrze (przewodność cieplna ok. $0,03 \mathrm{~W} / \mathrm{m} \cdot \mathrm{K})$,

- faza ciekła - woda $(0,6 \mathrm{~W} / \mathrm{m} \cdot \mathrm{K})$,

- faza stała - szkielet gruntowy (od ok. 1,2 W/m·K do ok. $9,0 \mathrm{~W} / \mathrm{m} \cdot \mathrm{K})$.

Znajomość wartości przewodności cieplnej poszczególnych faz umożliwia zapis sekwencji wartości przewodności cieplnej dla składników oraz ośrodka gruntowego (Różański, 2018):

$$
\lambda_{p} \leq \lambda^{d r y} \leq \lambda_{w} \leq \lambda^{s a t} \leq \lambda_{s}
$$

gdzie:

$\lambda_{p}$ - przewodność cieplna powietrza,

$\lambda^{d r y}$ - przewodność gruntu wysuszonego do stałej masy,

$\lambda_{w}$ - przewodność cieplną wody,

$\lambda^{\text {sat }}$ - przewodność cieplną próbki nawodnionej,

$\lambda_{\mathrm{s}}-$ przewodność cieplną szkieletu gruntowego.

Czynnikiem mającym kluczowy wpływ na wartość efektywnej przewodności termicznej ośrodka gruntowego jest zawartość wody w przestrzeni porowej. Ponieważ przewodność cieplna wody jest wielokrotnie wyższa niż przewodność cieplna powietrza, to grunt suchy (dwufazowy) charakteryzuje się mniejszą efektywną przewodnością termiczną niż grunt nasycony wodą. Jednak w przypadku gruntów spoistych w miarę wzrostu wilgotności po osiagnięciu stanu plastycznego gruntu spada jego gęstość objętościowa. 


\section{Wykonywanie oznaczeń laboratoryjnych przewodności cieplnej gruntów Soil thermal conductivity testing scheme}

\section{GRUNTY NIESPOISTE \\ NON-COHESIVE SOILS}

\section{GRUNTY SPOISTE \\ COHESIVE SOILS}

\section{Komplet badań właściwości fizycznych, w tym:}

A set of tests for physical properties, including:

\section{wilgotność naturalna, skład granulometryczny, gęstość objętościowa}

moisture content, particle size distribution, bulk density wilgotność naturalna, skład granulometryczny, gęstość objętościowa, parametry stanu

moisture content, particle size distribution, bulk density, consistency

\section{Pomiary przewodności termicznej Thermal conductivity tests}

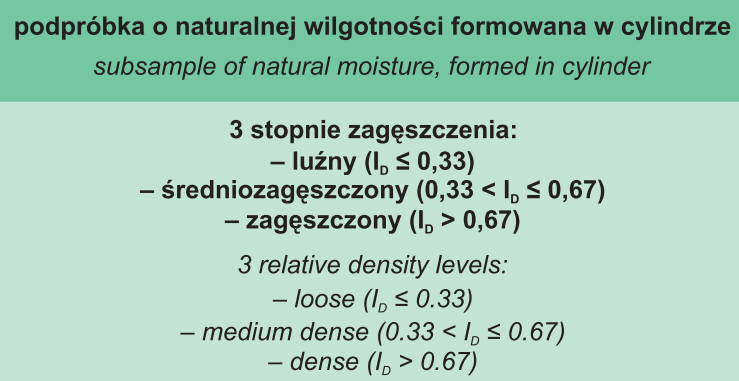
thermal conductivity testing cycle (3 measurements)

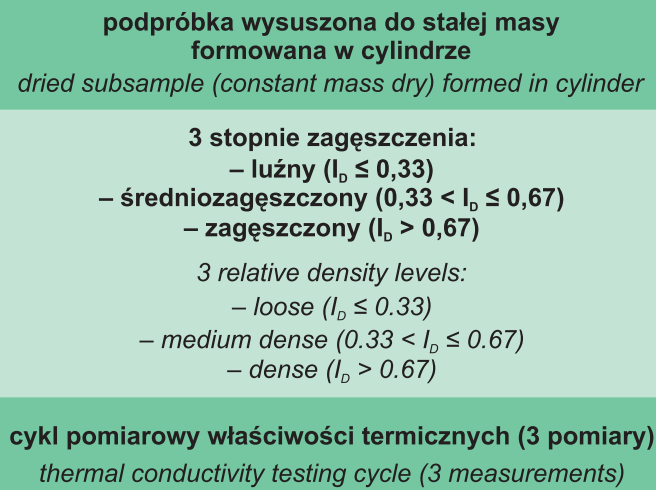

cykl pomiarowy właściwości termicznych (3 pomiary) thermal conductivity testing cycle ( 3 measurements)

podpróbka w pełni nasycona wodą formowana w cylindrze subsample fully saturated with water, formed in cylinder

\section{3 stopnie zagęszczenia:} - luźny $\left(I_{0} \leq 0,33\right)$

cykl pomiarowy właściwości termicznych (3 pomiary) thermal conductivity testing cycle ( 3 measurements) cykl pomiarowy właściwości termicznych (3 pomiary)

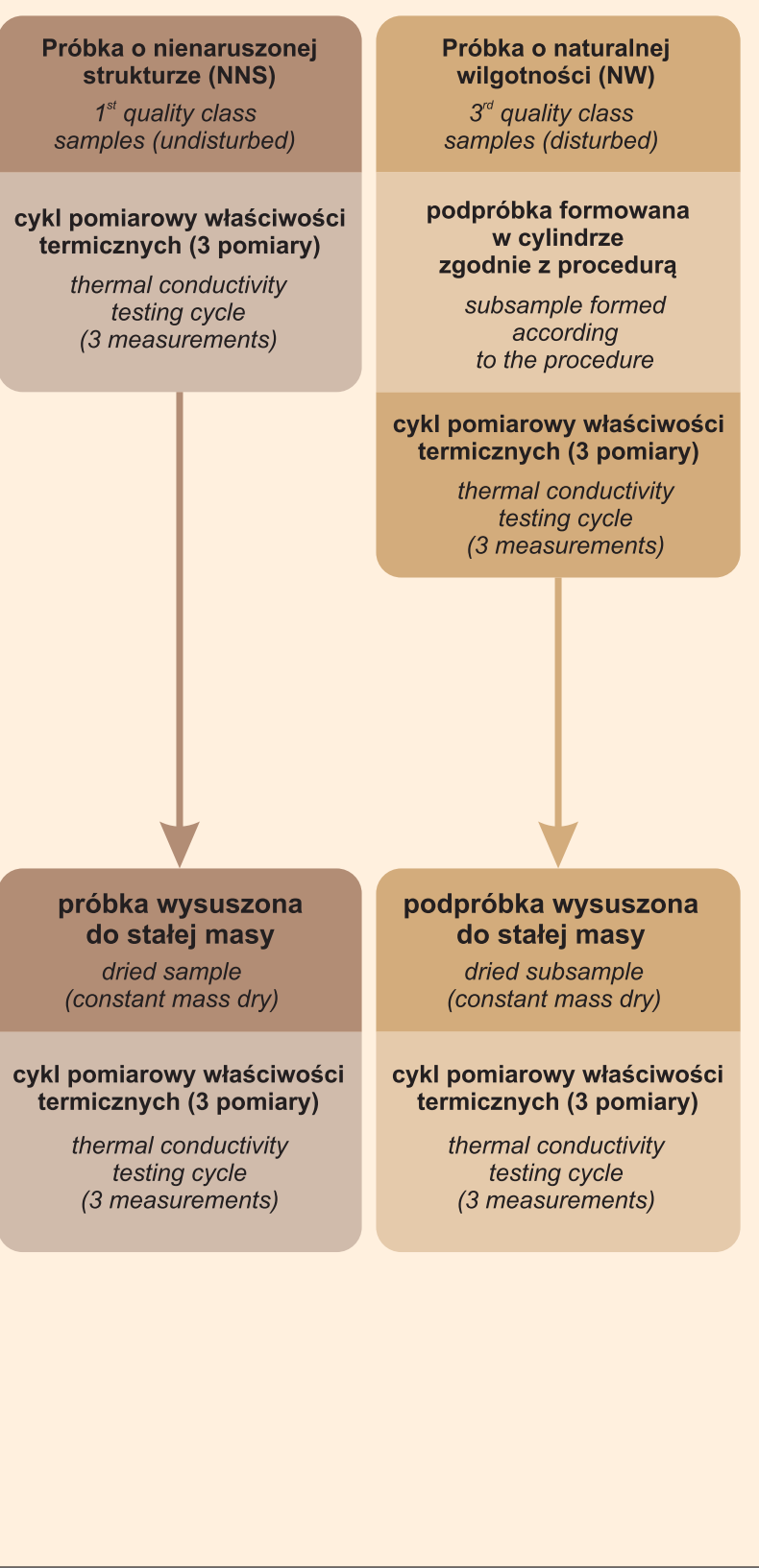

Ryc. 1. Schemat prowadzenia seryjnych oznaczeń laboratoryjnych przewodności cieplnej gruntów w PIG-PIB (Łukawska i in., 2020) Fig. 1. Diagram of serial effective thermal conductivity measurements in PGI-NRI (Lukawska i in., 2020) 

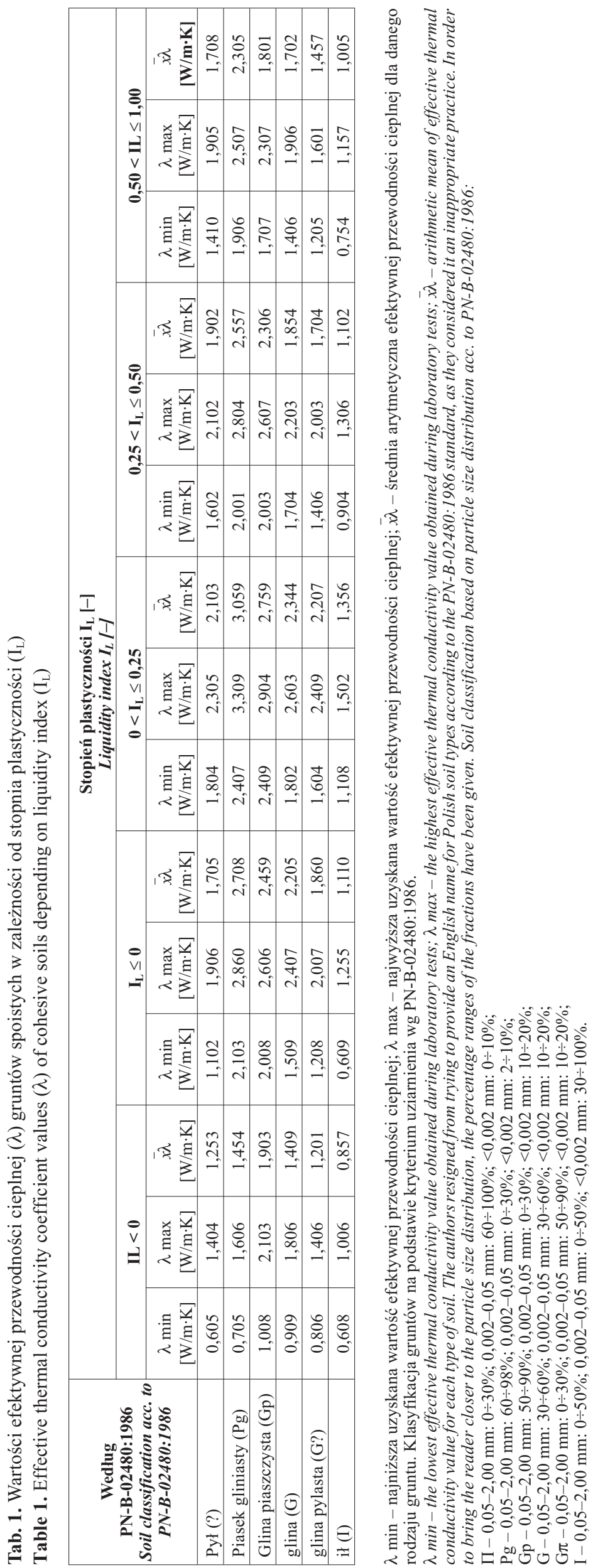

Cząstki szkieletu gruntowego tracą ze sobą kontakt, co powoduje spadek wartości przewodności cieplnej.

W gruncie suchym przewodzenie ciepła odbywa się przez kontakty międzyziarnowe, w związku z czym efektywna przewodność termiczna gruntu zależy od jego porowatości i gęstości objętościowej, czyli upakowania ziaren w jednostce objętości (Lu i in., 2007).

Wpływ na wartość efektywnej przewodności termicznej gruntu ma również skład mineralny szkieletu gruntowego. Kwarc charakteryzuje się jedną z najwyższych przewodności cieplnych wśród minerałów tworzących grunty - średnio 7,7 W/m·K (Čermák, Rybach, 1982). Co za tym idzie, im większa jest zawartość ziaren i cząstek kwarcowych w szkielecie gruntowym, tym wyższa jest efektywna przewodność cieplna gruntu.

W polskich warunkach minerały tworzace grunty niespoiste oraz frakcję pyłową to w większości kwarc, skalenie i minerały ciemne. Na frakcję iłową składają się przede wszystkim minerały ilaste - illit, montmorylonit, kaolinit (Kaczyński, 2017). Analizując wartości przewodności cieplnej minerałów, tworzących poszczególne frakcje gruntowe, Tian $\mathrm{i}$ in. (2016) wyprowadzili następującą zależność:

$$
\overline{\lambda_{C l}}<\overline{\lambda_{S i}}<\overline{\lambda_{S a}}
$$

Symbole oznaczają uśrednione wartości przewodności cieplnej $(\lambda)$ minerałów tworzących szkielet gruntowy w odniesieniu do poszczególnych frakcji $(\mathrm{Cl}$ - frakcja iłowa, $\mathrm{Si}$ - frakcja pyłowa, $\mathrm{Sa}-$ frakcja piaskowa).

Kolejnym czynnikiem, który ma wpływ na efektywną przewodność cieplną ośrodka gruntowego, jest jego porowatość, rozumiana jako stosunek objętości porów w danej próbce gruntu do objętości całego gruntu. Istotny wpływ na wartość przewodności termicznej gruntu ma medium wypełniające pory (woda i/lub powietrze). Spadek porowatości gruntu powoduje jednoczesny wzrost jego gęstości objętościowej i zwiększenie powierzchni kontaktu między ziarnami, co prowadzi do wzrostu przewodności termicznej ośrodka.

Wyniki laboratoryjnych pomiarów efektywnej przewodności termicznej gruntów zostały zaprezentowane $\mathrm{w}$ formie tabel $\mathrm{i}$ wykresów (tab. 1 i 2 , ryc. 2 i 3). W trakcie prac przebadano ok. 30 próbek z każdego rodzaju gruntu ujętego w tabelach. Testy wykonano dla 5 przedziałów wilgotności/stopnia plastyczności. Na każdej próbce wykonano 3 pomiary przewodności cieplnej, co dało w sumie ponad 5400 oznaczeń parametru $\lambda$.

\section{EFEKTYWNA PRZEWODNOŚĆ TERMICZNA GRUNTÓW SPOISTYCH}

Uzyskane wartości efektywnej przewodności cieplnej w gruntach spoistych początkowo zwiększają się wraz ze wzrostem wilgotności, a następnie zaczynają spadać (ryc. 2). Dla wszystkich gruntów spoistych najwyższe wartości przewodności termicznej uzyskano dla wskaźnika plastyczności w przedziale $0<\mathrm{I}_{\mathrm{L}} \leq 0,25$ (stan twardoplastyczny). Wśród analizowanych gruntów spoistych najwyższe war- 

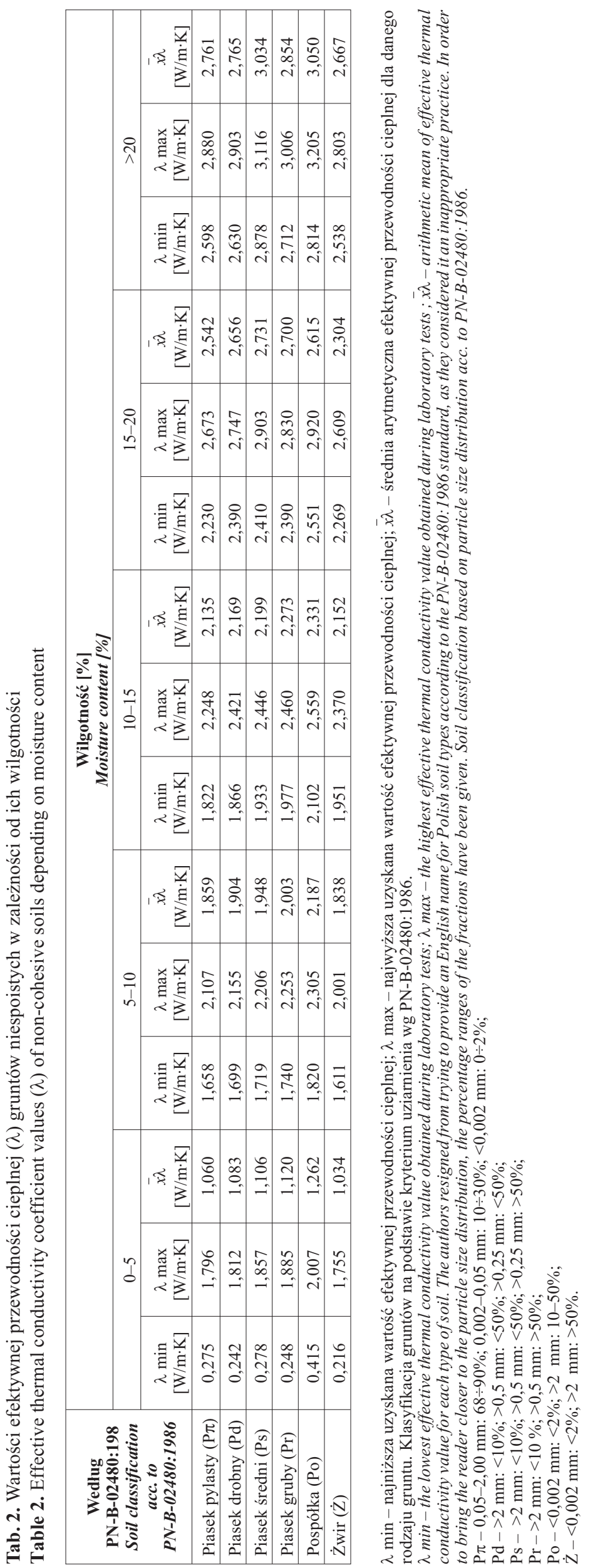

tości efektywnej przewodności cieplnej wykazują piaski gliniaste (do 3,309 W/m·K w stanie twardoplastycznym). Ma to związek z dużą zawartością frakcji piaskowej tego rodzaju gruntu (60-98\% wg PN-B-02480:1986), która w polskich warunkach składa się w głównej mierze z kwarcu charakteryzującego się wysoką przewodnością termiczną (Čermák, Rybach, 1982; Kaczyński, 2017). Najniższe wartości efektywna przewodność termiczna przyjmuje w gruntach bardzo spoistych - iłach $(0,6 \mathrm{~W} / \mathrm{m} \cdot \mathrm{K}$ w stanie zwartym do $1,5 \mathrm{~W} / \mathrm{m} \cdot \mathrm{K}$ w stanie twardoplastycznym). Wynika to z dużej zawartości minerałów ilastych, które charakteryzują się niską przewodnością cieplną (Midttomme i in., 1998).

Jak wspomniano wcześniej, po osiagnięciu przez grunt stanu plastycznego $\left(0,25<\mathrm{I}_{\mathrm{L}} \leq 0,50\right)$, uzyskane wartości efektywnej przewodności termicznej maleją, co jest spowodowane mniejszą gęstością objętościową, jak również utratą kontaktu między cząstkami gruntu.

\section{EFEKTYWNA PRZEWODNOŚĆ TERMICZNA GRUNTÓW NIESPOISTYCH}

Podobnie jak w przypadku gruntów spoistych, największy wpływ na wartość przewodności termicznej gruntów ma medium wypełniające pory gruntu. W gruntach niespoistych obserwujemy wzrost efektywnej przewodności termicznej wraz ze wzrostem ich wilgotności. Najbardziej dynamiczny wzrost wartości przewodności termicznej następuje w przedziale $0-5 \%$ wilgotności. W miarę nasycania się porów gruntu wodą przyrost wartości przewodności cieplnej staje się wolniejszy. Najwyższe wartości efektywnej przewodności termicznej są obserwowane w gruntach niespoistych w pełni nasyconych wodą (dwufazowych).

Spośród analizowanych gruntów niespoistych najniższe wartości efektywnej przewodności termicznej uzyskano dla żwirów (od $0,216 \mathrm{~W} / \mathrm{m} \cdot \mathrm{K}$ w przedziale wilgotności $0-5 \%$ do $2,803 \mathrm{~W} / \mathrm{m} \cdot \mathrm{K}$ w przedziale powyżej $20 \%$ wilgotności). Żwiry jako grunty równomiernie uziarnione, składające się z obtoczonych ziaren, charakteryzują się stosunkowo niskimi wartościami gęstości objętościowej i wysokimi wartościami porowatości. Równomierne uziarnienie przekłada się na wyższy niż w innych gruntach stosunek objętości porów do objętości szkieletu gruntowego (Kaczyński, 2017) i bezpośrednio na pogorszenie kontaktu między poszczególnymi ziarnami.

Analogicznie, najwyższe wartości efektywnej przewodności cieplnej (od $0,415 \mathrm{~W} / \mathrm{m} \cdot \mathrm{K}$ w przedziale wilgotności $0-5 \%$ do $3,205 \mathrm{~W} / \mathrm{m} \cdot \mathrm{K}$ w przedziale powyżej 20\% wilgotności) uzyskano dla pospółek - gruntów bardzo dobrze uziarnionych, a co za tym idzie łatwo zagęszczających się, o bardzo dobrym kontakcie między ziarnami szkieletu gruntowego (ryc. 3).

\section{PODSUMOWANIE}

Opracowana w CBGS metodyka wykonywania seryjnych pomiarów efektywnej przewodności 


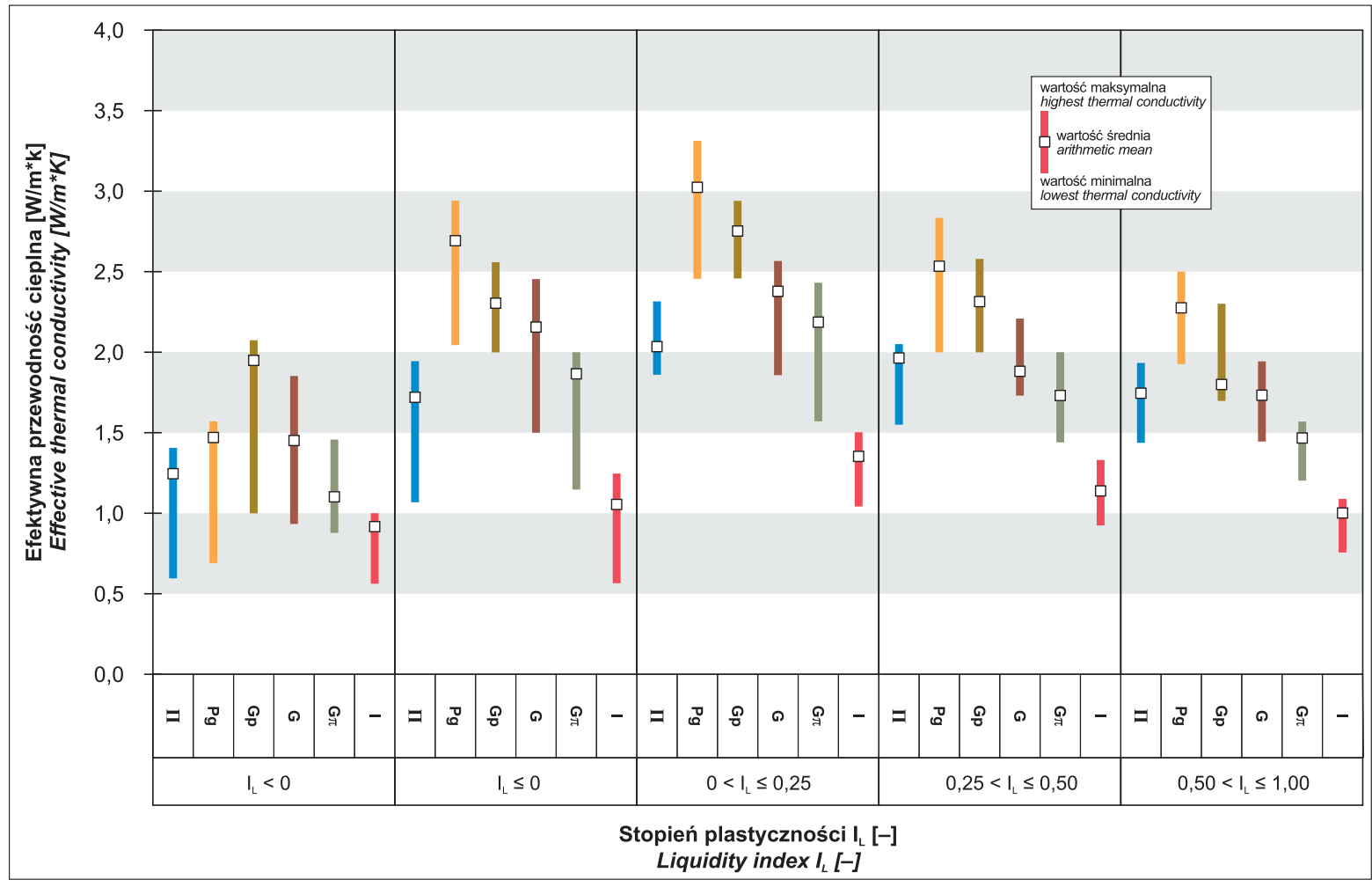

Ryc. 2. Rozkład wartości efektywnej przewodności cieplnej $(\lambda)$ gruntów spoistych w zależności od stopnia plastyczności $\left(\mathrm{I}_{\mathrm{L}}\right)$. Rodzaj gruntów zgodny z PN-B-02480:1986 (patrz tab. 1)

Fig. 2. Distribution of effective thermal conductivity coefficient values $(\pi)$ in cohesive soils depending on liquidity index $\left(\mathrm{I}_{\mathrm{L}}\right)$. Soil classification based on particle size distribution acc. to PN-B-02480:1986 - see table 1

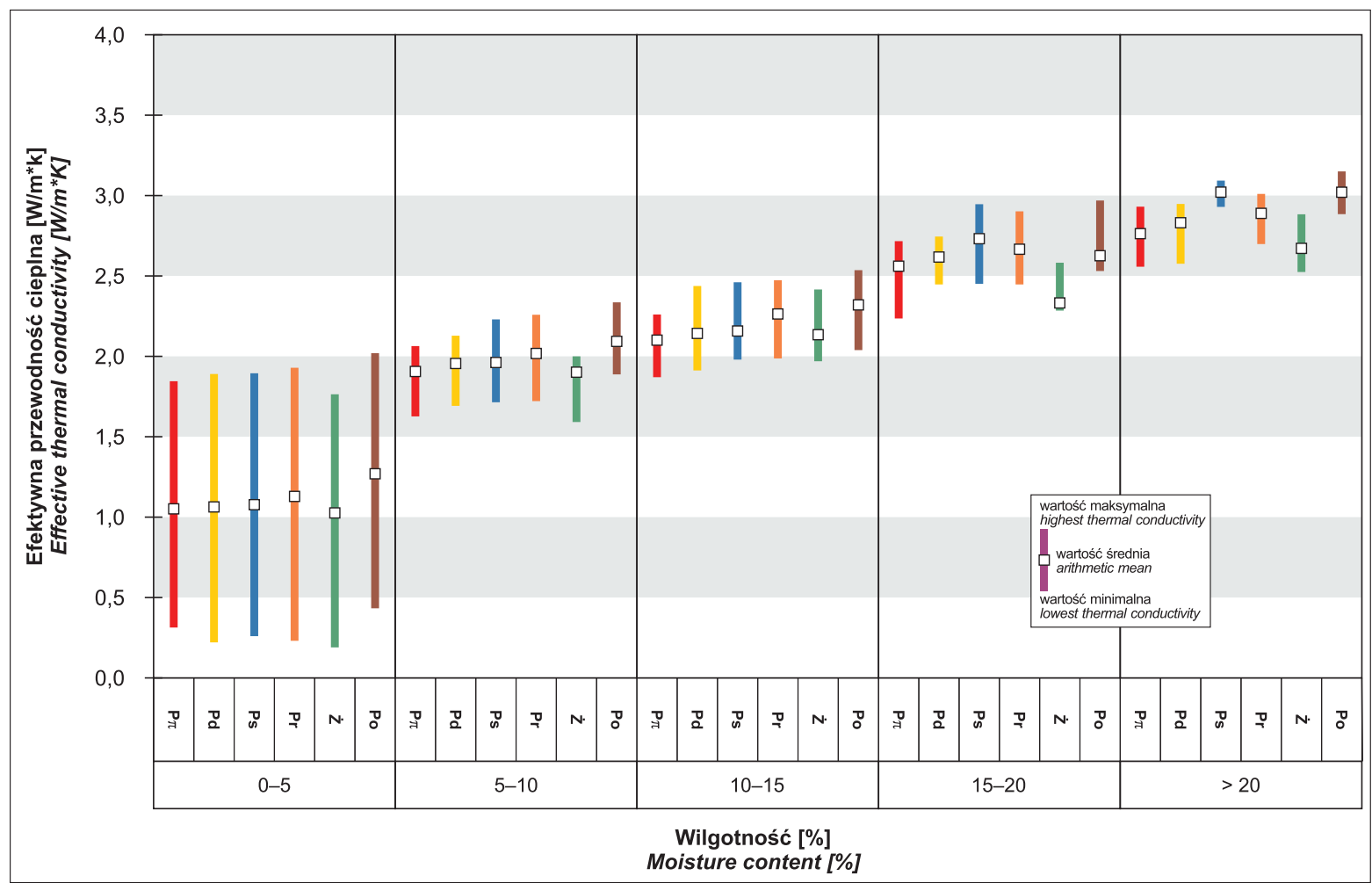

Ryc. 3. Rozkład efektywnej przewodności cieplnej gruntów niespoistych w zależności od ich wilgotności. Rodzaj gruntów zgodny z PN-B-02480:1986 (patrz tab. 2)

Fig. 3. Distribution of effective thermal conductivity coefficient values $(\pi)$ in non-cohesive soils depending on moisture content. Soil classification based on particle size distribution acc. to PN-B-02480:1986 (see table 2)

termicznej zapewnia powtarzalne i wiarygodne wyniki. Krótki czas przygotowania próbki i wykonania badania umożliwia zasilanie bazy danych dużą liczbą parametrów termicznych różnego rodzaju gruntów w zestawieniu z ich 
właściwościami fizycznymi. Dane zgromadzone w bazie umożliwiają określenie wpływu właściwości fizycznych gruntu na jego efektywną przewodność termiczną.

W pracy autorzy skupili się na przedstawieniu zależności między wartością efektywnej przewodności termicznej gruntów a ich wilgotnością. W gruntach niespoistych wartość efektywnej przewodności termicznej wzrasta systematycznie wraz ze wzrostem wilgotności, aż do osiąnnięcia pełnej saturacji gruntu. W gruntach spoistych najwyższe wartości efektywnej przewodności termicznej otrzymano W stanie twardoplastycznym $\left(0<\mathrm{I}_{\mathrm{L}} \leq 0,25\right)$. Wartość przewodności termicznej maleje zarówno ze spadkiem wartości wilgotności poniżej granicy plastyczności (stan zwarty i półzwarty) oraz ze wzrostem wilgotności po osiagnięciu stanu plastycznego $\left(0,25<\mathrm{I}_{\mathrm{L}} \leq 0,50\right)$ i miękkoplastycznego $\left(0,50<\mathrm{I}_{\mathrm{L}} \leq 1,00\right)$.

Wartość analizowanego parametru wykazuje także znaczną zmienność w zależności od uziarnienia badanego gruntu. W gruntach spoistych najwyższe wartości efektywnej przewodności cieplnej uzyskano w piaskach gliniastych, a najniższe w gruntach bardzo spoistych o dużej zawartości minerałów ilastych - iłach. Ma to związek ze stosunkiem zawartości kwarcu do zawartości minerałów ilastych w badanej próbce i różnicą w ich właściwościach termicznych.

Zgromadzone w bazie danych właściwości termiczne gruntów informacje pozwoliły na skonstruowanie wykresów zależności efektywnej przewodności termicznej różnych rodzajów gruntów od ich wilgotności i przedstawienia wyników w formie tabel. Dane te są następnie wykorzystywane $\mathrm{w}$ procesie parametryzacji geotermalnych modeli $3 \mathrm{D}$ wykonywania seryjnych map potencjału płytkiej geotermii, które mogą być podstawą do szacowania liczby i głębokości otworów potrzebnych do uzyskania pożądanej ilości energii.

Znajomość wartości efektywnej przewodności termicznej poszczególnych rodzajów gruntu umożliwia zaprojektowanie wydajnej instalacji i maksymalne wykorzystanie potencjału cieplnego podłoża gruntowego. Przekłada się to na zmniejszenie kosztów wykonania i użytkowania wymiennika ciepła.

Po wykonaniu przedstawionej w artykule serii pomiarów autorzy uznają za konieczne rozszerzenie istniejącej bazy danych o właściwości cieplne gruntów w ujęciu regionalnym i litogenetycznym, co będzie przedmiotem dalszych badań.

Prace zostały zrealizowane w ramach zadania państwowej służby geologicznej (PSG) pod nazwą Ocena potencjału energetycznego i uwarunkowań środowiskowych dla wsparcia zrównoważonego rozwoju geotermii niskotemperaturowej finansowanego ze środków Narodowego Funduszu Ochrony Środowiska i Gospodarki Wodnej. Autorzy dziękują Panu dr. Zbigniewowi Frankowskiemu oraz recenzentkom - dr Alicji Bobrowskiej i dr Annie Bąkowskiej, za cenne uwagi i komentarze, które przyczyniły się do opracowania ostatecznej wersji artykułu.

\section{LITERATURA}

ANDERS G.J., RADHAKRISHNA H.S. 1988 - Power cable thermal analysis with consideration of heat and moisture transfer in the soil. IEEE Transactions on Power Delivery, 3 (4): 1280-1288.

BARALIS M., BARLA M., BOGUSZ W., DI DONNA A., RYŻYŃSKI G. ŻERUN M. 2018 - Geothermal potential of the NE extension Warsaw (Poland) metro tunnels. Environ. Geotech., 1-13.
BOGUSZ W. 2017 - Możliwość zastosowania fundamentów termoaktywnych w budownictwie mostowym. Mosty, 1: 42-45.

ČERMÁK V., RYBACH L. 1982 - Thermal conductivity and specific heat of minerals and rocks. Landolt-Börnstein: Numerical Data and Functional Relationships in Science and Technology, New Series, Group V (Geophysics and Space Research), Vol. Ia, (Physical Properties of Rocks), edited by G. Angenheister, Springer, Berlin-Heidelberg: 305-343.

FAROUKI O.T. 1981 - Thermal Properties of Soils. CRREL Monograph 81-1, New Hampshire, US.

FLORIDES G.A., POULOUPATIS P.D., KALOGIROU S., MESSARITIS V., PANAYIDES I., ZOMENI Z., PARTASIDES G., LIZIDES A., SOPHOCLEOUS E., KOUTSOUMPAS K. 2011 - The geothermal characteristics of the ground and the potential of using ground coupled heat pumps in Cyprus. Energies, 36 (8): 5027-5036.

KACZYŃSKI R.R. 2017 - Warunki geologiczno-inżynierskie na obszarze Polski. Państw. Inst. Geol., Warszawa.

KD2 Pro thermal properties analyzer operator's manual version 4. Decagon Devices, Pullman, Washington, US, 2016.

KŁONOWSKI M.R., KOCYŁA J., RYŻYŃSKI G., ŻERUŃ M. 2020 Evaluation and statistical interpretation of low-temperature geothermal energy potential for selected locations in Poland. Geol. Quart., 64 (2): 506-514.

LU S., REN T., GONG Y., HORTON R. 2007 - An improved model for predicting soil thermal conductivity from water content at room temperature. Soil Sci. Soc. Am. J., 71 (1): 8-14.

ŁUKAWSKA A., RYŻYŃSKI G., ŻERUŃ M. 2020 - Serial Laboratory Effective Thermal Conductivity Measurements of Cohesive and Non-cohesive Soils for the Purpose of Shallow Geothermal Potential Mapping and Databases - Methodology and Testing Procedure Recommendations. Energies, https://doi.org/10.3390/en13040914

MAGLIĆ K.D., CEZAIRLIYAN A., PELETSKY V.E. (red.) 1992 - Compendium of Thermophysical Property Measurement Methods: Vol. 2 Recommended Measurement Techniques and Practices. Springer, Boston, US. MIDTTOMME K., ROALDSET E., AAGAARD P. 1998 - Thermal conductivity claystones and mudstones. Clay Minerals, 33: 131-145.

MYSLINSKA E. 2006 - Laboratoryjne badania gruntów. Wyd. Nauk. PWN, Warszawa.

PN-B-02480:1986 Grunty budowlane - Określenia, symbole, podział i opis gruntów.

PN-B-04481:1988 Grunty budowlane - Badania próbek gruntu.

PN-EN 1997-2:2007 Eurokod 7: Projektowanie geotechniczne, Część 2: Rozpoznanie i badanie podłoża gruntowego.

PN-EN ISO 17892 Rozpoznanie i badania geotechniczne - Badania laboratoryjne gruntów, Część 1-12.

POPOV Y., BEARDSMORE G., CLAUSER C., ROY S. 2016 - ISRM suggested methods for determining thermal properties of rocks from laboratory tests at atmospheric pressure. Rock Mech. Rock Eng., 49 (10): 4179-4207.

RAMOS R., ARESTI L., CHRISTODOULIDES P., VIEIRA A., FLORIDES G. 2018 - Assessment and Comparison of Soil Thermal Characteristics by Laboratory Measurements. In International Symposium on Energy Geotechnics, 155-162.

ROBERTSON E.C. 1988 - Thermal properties of rocks. Open-File Report no. 88-441 US Geological Survey.

RYŻYŃSKI G., BOGUSZ W. 2016 - City-scale perspective for thermoactive structures in Warsaw. Environ.Geotech., 3 (4): 280-290.

RYŻYŃSKI G., ŁUKAWSKA A., ŻERUŃ M. 2018 - Wytyczne do prowadzenia seryjnych oznaczeń laboratoryjnych przewodności cieplnej gruntów spoistych i niespoistych na potrzeby sporządzania map i baz danych potencjału geotermii niskotemperaturowej. Tech. Posz. Geol., Geotermia, Zrównoważony Rozwój, 57 (2): 229-230.

RYŻYŃSKI G., ŻERUŃ M., KOCYŁA J., KŁONOWSKI M.R. 2020 Estimation of Potential Low-temperature Geothermal Energy Extraction from the Closed-loop Systems Based on Analysis, Interpretation and Reclassification of Geological Borehole Data in Poland. Proceedings of World Geothermal Congress 2020, Reykjavik, Iceland, 26 April-2 May. TIAN Z., LU Y., HORTON R., REN T. 2016 - A simplified de Vries? based model to estimate thermal conductivity of unfrozen and frozen soil. Europ. J. Soil Sci., 67(5): 564-572.

VIEIRA A., ALBERDI-PAGOLA M., CHRISTODOULIDES P., JAVED S., LOVERIDGE F., NGUYEN F., CECINATO F., MARANHA J., FLORIDES G., PRODAN J., VAN LYSEBETTEN G., RAMALHO E., SALCIARINI D., GEORGIEV A., ROSIN-PAUMIER S., POPOV R., LENART S., POULSEN S.E., RADIOTI G. 2017 - Characterisation of Ground Thermal and Thermo-Mechanical Behaviour for Shallow Geothermal Energy Applications. Energies, 10 (12), doi:10.3390/en10122044

Praca wpłynęła do redakcji 13.07.2021 r. Akceptowano do druku 30.08.2021 r. 